\title{
The Civil Rights Movement
}


Studies in Contemporary History

Series Editors: T. G. Fraser and J. O. Springhall

\title{
PUBLISHED
}

T. G. Fraser The Arab-Israeli Conflict

Raymond Pearson The Rise and Fall of the Soviet Empire

William T. Martin Riches The Civil Rights Movement

Dennis B. Smith Japan since 1945

\section{FORTHCOMING}

James Loughlin The Ulster Question Since 1945

Stephen Ryan The United Nations and International Politics

\author{
Studies in Contemporary History \\ Series Standing Order \\ ISBN 978-0-333-61100-5 \\ ISBN 978-1-349-25880-2 (eBook) \\ DOI 10.1007/978-1-349-25880-2
}

You can receive future titles in this series as they are published by placing a standing order. Please contact your bookseller or, in the case of difficulty, write to us at the address below with your name and address, the title of the series and the ISBN quoted above.

Customer Services Department, Macmillan Distribution Ltd Houndmills, Basingstoke, Hampshire RG21 6XS, England 


\title{
The Givil Rights Movement StrugGle AND Resistance
}

\author{
William T. Martin Riches
}


() William T. Martin Riches 1997

All rights reserved. No reproduction, copy or transmission of this publication may be made without written permission.

No paragraph of this publication may be reproduced, copied or transmitted save with written permission or in accordance with the provisions of the Copyright, Designs and Patents Act 1988, or under the terms of any licence permitting limited copying issued by the Copyright Licensing Agency, 90 Tottenham Court Road, London W1P 9HE.

Any person who does any unauthorised act in relation to this publication may be liable to criminal prosecution and civil claims for damages.

The author has asserted his rights to be identified as the author of this work in accordance with the Copyright, Designs and Patents Act 1988.

First published 1997 by

MACMILLAN PRESS LTD

Houndmills, Basingstoke, Hampshire RG21 6XS

and London

Companies and representatives

throughout the world

ISBN 978-0-333-61100-5

ISBN 978-1-349-25880-2 (eBook)

DOI 10.1007/978-1-349-25880-2

A catalogue record for this book is available from the British Library.

This book is printed on paper suitable for recycling and made from fully managed and sustained forest sources.

$\begin{array}{rrrrrrrrrr}10 & 9 & 8 & 7 & 6 & 5 & 4 & 3 & 2 & 1 \\ 06 & 05 & 04 & 03 & 02 & 01 & 00 & 99 & 98 & 97\end{array}$

Printed in Hong Kong

Published in the United States of America 1997 by

ST. MARTIN'S PRESS, INC.,

Scholarly and Reference Division

175 Fifth Avenue, New York, N.Y. 10010

ISBN 978-0-312-17403-9 cloth

ISBN 978-0-312-17404-7 paperback 
To Judy 


\section{Contents}

Series Editors' Preface

$\mathbf{x}$

Preface

xii

Acknowledgements

XV

Glossary

xvi

List of Acronyms

xix

Basic Chronology

$\mathrm{xxi}$

Introduction

Slavery and the Civil War

Reconstruction

Freedmen Abandoned

The Depression and New Deal

World War II

Black Nationalism and Changing Attitudes

1 Transformation of Politics: Civil Rights 1945-58 15

Fair Employment

Democrats Transformed

The 1948 Election

Integrating the Military

African Americans and Labour $\quad 22$

Eisenhower

The Brown Decision $\quad 24$

Little Rock $\quad 27$

The FBI and Black America $\quad 29$

The 1957 Civil Rights Act $\quad 30$

Truman, the Cold War and Civil Rights 32

Eisenhower and the Cold War

Indochina $\quad 36$

Black Nationalism $\quad 37$ 
2 Grass-Roots Resistance in the South 39

Louisiana Protest 41

Mrs Rosa Parks 42

Martin Luther King Jr and the Boycott

White Resistance $\quad 47$

'Not a One Man Show' $\quad 49$

White Sympathisers $\quad 50$

3 A New Frontier? JFK, Civil Rights and Mass Protest 56

The Greensboro Sit-In $\quad 56$

The Nashville Sit-In $\quad 59$

King Meets Kennedy $\quad 61$

Executive Action $\quad 63$

The Freedom Rides $\quad 66$

The Integration of 'Ole Miss' $\quad 67$

Internal Divisions and External Pressures $\quad 69$

The Albany Movement $\quad 70$

King and Birmingham, Alabama 72

The March on Washington $\quad 73$

4 The Great Society and the Limits of Liberalism 76

The Civil Rights Act 1964

The Mississippi Freedom Democratic Party 79

The 1964 Campaign $\quad 83$

The Challenge at Selma $\quad 84$

'Bloody Sunday' and the March to Montgomery 85

The Voting Rights Act 1965

Civil Rights and the Anti-Vietnam War Movement $\quad 89$

King Goes to Chicago $\quad 91$

The FBI and Martin Luther King $\quad 92$

The Black Panther Party, Malcolm X and Black Power $\quad 92$

Murder in Memphis $\quad 95$

5 Nixon, Reagan and the New Right 98

Chicago, $1968 \quad 98$

Nixon's Southern Strategy $\quad 100$

Nixon and Abernathy 102

Nixon and Affirmative Action 103

Supreme Court Nominations $\quad 104$

$\begin{array}{ll}\text { School Desegregation } & 106\end{array}$ 
The Politics of Euphemism 109

Black Capitalism 109

Ronald Reagan and the New Right 112

Was Reagan a Racist? 113

The New Right Budget 114

The Commission on Civil Rights and the IRS 116

Renewal of the Voting Rights Act 118

6 Transformations: A New South? 121

The Senator 123

The President 127

Mayors, Congressmen and the Governor 131

The Judge - Frank Johnson 133

$\begin{array}{ll}\text { The Students } & 136\end{array}$

7 Ripples from the Pond 142

African American Women $\quad 142$

The Women's Movement 144

Gay Liberation $\quad 150$

Native Americans $\quad 154$

Red Power $\quad 157$

8 Bush, Clinton, Willie Horton and American Politics 161

Willie Horton and the 1988 Campaign 162

Rodney King and the Los Angeles Police Department 164

George Bush and African Americans $\quad 165$

Appointing a Judge $\quad 167$

The Women's Movement and the New Conservatism 169

George Bush and the Gay Community 170

Civil Rights for the Disabled $\quad 172$

The Election Campaign of 1992

Clinton and African Americans $\quad 174$

Clinton and the Women's Movement 176

Clinton, Gays and the Military 176

$\begin{array}{ll}\text { Epilogue } & 179\end{array}$

$\begin{array}{ll}\text { Bibliography } & 181\end{array}$

Index 188 


\section{Series Editors' Preface}

There are those, politicians among them, who feel that historians should not teach or write about contemporary events and people many of whom are still living - because of the difficulty of treating such matters with historical perspective, that it is right to draw some distinction between the study of history and the study of current affairs. Proponents of this view seem to be unaware of the concept of contemporary history to which this series is devoted, that the history of the recent past can and should be written with a degree of objectivity. As memories of the Second World War recede, it is surely time to place in perspective the postwar history that has shaped all our lives, whether we were born in the 1940s or the 1970s.

Many countries - Britain, the United States and Germany among them - allow access to their public records under a thirty-year rule, opening up much of the postwar period to archival research. For more recent events, diaries, memoirs, and the investigations of newspapers and television, confirm the view of the famous historian Sir Lewis Namier that all secrets are in print provided you know where to look for them. Contemporary historians also have the opportunity, denied to historians of earlier periods, of interviewing participants in the events they are analysing. The problem facing the contemporary historian is, if anything, the embarrassment of riches.

In any case, the nature and extent of world changes since the late 1980s have clearly signalled the need for concise discussion of major themes in post-1945 history. For many of us the difficult thing to grasp is how dramatically the world has changed over recent years: the collapse of the Soviet Union and Russian communism; the end of Soviet hegemony over eastern Europe; the unification of Germany; the end of the Cold War; America's sense of a 'new world 
order'; the pace of integration in the European Union; the disintegration of Yugoslavia; the Middle East peace settlement; the continuing economic strength of Japan. Writing in a structured and cogent way about these seismic changes is what makes contemporary history so challenging, and we hope that the end result will convey some of this excitement and interest to our readers.

The general objective of this series, written entirely by members of the School of History, Philosophy and Politics of the University of Ulster, is to offer concise and up-to-date treatments of postwar themes considered of historical and political significance, and to stimulate critical thought about the theoretical assumptions and conceptual apparatus underlying interpretation of the topics under discussion. The series should bring some of the central themes and problems confronting students and teachers of recent history, politics and international affairs into sharper focus than the textbook writer alone could provide. The blend required to write contemporary history that is both readable and easily understood but also accurate and scholarly is not easy to achieve, but we hope that this series will prove worthwhile for both students and teachers interested in world affairs since 1945.

University of Ulster

T. G. Fraser

J. O. Springhall 


\section{PrefaCe}

A friend at Harvard University in 1964 enquired about the places that my wife and I would visit during our travels in the United States from our home in Canada. When we informed him that we were going to visit the southern states, including Alabama and Mississippi, he was very concerned about our safety and pressed us to buy a flag and put it in the front of the car. He warned us that we would be mistaken for civil rights 'outside agitators' and the locals would not know that our Ontario licence plate proved we were from Canada but would assume it was just another northern state. We assured him that we would take the necessary precautions.

As foreigners we were naive about the dangers we faced and, more important, equally unaware of the 'etiquette of segregation'. This became apparent as we approached the town of Biloxi, Mississippi. We were thirsty and just after crossing the city limits we stopped at a restaurant for a drink. It was crowded and we sat at the counter and I ordered two coffees. The woman did not respond. I asked for a second time and still no acknowledgement. I assumed it must be my accent and, with a slightly raised voice, I spoke slowly and distinctly and repeated my order. The woman turned and fled. Before we could leave a man appeared and asked politely what we wanted and I repeated my order. Looking at the woman he told her to give us the cups of coffee. Throughout this almost surrealistic exchange we were aware that the conversations of the other customers had stopped and there was just an oppressive silence. Looking around the restaurant we realised why. We were the only white couple in the place. With my long hair and beard it must have seemed that I was one of those civil rights 'trouble makers' and by 
integrating that cafe we had endangered the man, his wife and even his customers. Inadvertently we had defied segregation etiquette. In later years as graduate students at the University of Tennessee, Knoxville, our defiance of the South and its custom was never accidental.

The challenge in writing contemporary history is that the writer has lived through the events and some would argue that this makes considered judgement impossible. In my case it is even more difficult in that I was also a participant in a very small way in some of these events. However, this is not a participant's history, but rather seeks objectively to analyse the struggle of African Americans and other minorities, such as Native Americans, women and gays, to achieve equality in the years after World War II and those who sought to resist that change. I believe the intervening years and my views as an outsider living in Ireland have ensured some objectivity. I can only agree with Alan Dawley that 'the destiny of modern America was in the hands of the meek as well as the mighty'. As he points out, the struggles for racial justice and sexual equality were not simply a matter of the good versus the bad guys but 'there is no doubt that good and evil hung in the balance. In comprehending what happened, I have aspired to objectivity. But objectivity does not mean indifference. It matters very much how things turned out' (Dawley, 1991).

I am aware of the vital role played by Martin Luther King Jr in the civil rights movement and very conscious of the tragic consequences of his assassination in Memphis. However, in this study I have stressed the role of the civil rights movement as a mass movement and its interaction with those who held political power at the state, federal and local levels. It was the extraordinary courage and sacrifice of hundreds of thousands of the 'meek' that achieved the successes of the movement. I am very conscious that the movement had a profound influence on the ideology and tactics of those who participated in the anti-Vietnam War campaign. I have alluded frequently to the connections between the two but it has not been possible within the current text to elaborate on the antiwar movement. In addition, in chapter six, 'A New South?', it may be argued that $I$ have neglected the resurgence of racism and the role of the modern Ku Klux Klan. In my defence, I have pointed out in every chapter the resistance to the movement, but what has not been sufficiently acknowledged is the change in the attitudes of a 
significant number of southerners. Having lived in the South for many years, having studied at a southern university with students from all over the South, I believe that it is time that their voices were heard because they played a vital part in the struggle and many continue to do so today. I consider myself fortunate to include many of these people as my friends.

With the election of Richard Nixon in 1968 and with the Democratic party deeply divided, it seemed that the gains of the civil rights movement would be wiped out. A white friend who was a doctor in Tennessee, whose father was an illiterate sharecropper in Alabama, invited me and my wife to a dinner with friends, black and white, who were active in the civil rights movement and the antiVietnam War movement. We reminisced about the years that had passed and were fearful about the years ahead. Before we left he insisted that we all sit, listen and in the years ahead, when we were separated, to remember these words and try to live by them. He left the room and returned shortly. On that very late hot summer night in East Tennessee the small group of southerners - academics, ministers, atheists and the couple from the United Kingdom - sat and listened to the speech given by Martin Luther King Jr at the Washington rally of 1963.

So I say to you, my friends, that even though we must face the difficulties of today and tomorrow, I still have a dream. It is a dream deeply rooted in the American dream that one day this nation will rise up and live out the true meaning of its creed we hold these truths to be self-evident, that all men are created equal. 


\section{ACKNOWLEDGEMENTS}

I would like to thank the editors of the series, Tom Fraser and John Springhall, for their advice, criticism and support. I owe Professor Fraser a special debt of gratitude for his support of the American Studies programme at the University of Ulster at Jordanstown, at both the undergraduate and postgraduate levei. I would also like to thank the University for its support for my teaching and research for the last 20 years. In addition, I appreciate the criticism and advice given by my daughter, Julia Riches, who is currently studying at Georgetown University, and my son, Theo, who, despite his interest in medieval studies, has also read and commented on the manuscript. All lecturers owe great debts to their students who have helped in so many ways. It is invidious to single out individuals but I must thank Jacqueline Tine Nichols for persuading me to take a closer interest in the role of Native Americans, Leonora Campbell for introducing me to the struggle of Oglala women on the Pine Ridge Reservation (especially the poetry of Beth Brant), Simon Topping for a copy of his interview with James Meredith and David McAree for use of his taped interviews with African American women who worked with the Student Nonviolent Coordinating Committee. This book also owes much to friends from the South such as David Bowen, John Thomas, Tom Wilson, O. C. Richardson and Dan Pomeroy, to name just a few of my fellow graduate students from the University of Tennessee, Knoxville. Apart from my colleagues in England and Ireland who have provided constructive criticism, I would like especially to mention friends and members of the Milan Group for the Study of American History. This book is dedicated to my wife Judith, who made my academic career possible and who is my sternest critic and supporter. 


\section{Glossary}

Baby boom

Bossism

Bussing

Carpetbagger
This is an expression commonly used to describe the generation born in the late 1940s and 1950s, a period which saw a dramatic increase in childbirth in the United States.

The corruption of democratic government primarily in the urban centres of the United States enabled parties to control local government with the corrupt use of patronage. The most notorious city Boss in the nineteenth century was Boss Tweed of New York City and in the twentieth Mayor Richard Daley of Chicago.

After World War II southern states used bussing to consolidated schools, thereby eliminating many inferior rural institutions, in an effort to raise academic quality of the school system. However, the bus was also used to guarantee the segregation of white and black school children. In Swann v Carlotte-Mecklenburg (1974) the Supreme Court ordered the use of bussing to achieve racial integration.

An allegedly corrupt, white or black, Republican politician from the North who had moved to the South after the Civil War and who was active in southern politics. Carpetbaggers were seen by southerners as coming to rob the South because the only belongings they had with them were capable of being carried in a carpetbag. 
Filibustering

Governor

Great Society

Interposition

Jim Crow Laws

Ku Klux Klan (KKK)
A method of delaying or preventing legislation in Congress or in the state legislatures by prolonging the debate or using parliamentary procedures to prevent the passage of legislation.

The title of the leading executive officer of a state.

The 1964-68 liberal social and economic reform programme of President Lyndon Baines Johnson who hoped to resolve the problem of poverty in the United States and thereby to complete the New Deal begun by Johnson's hero, Franklin Delano Roosevelt.

The argument of southerners before the Civil War and during the civil rights movement that a state was sovereign and should interpose its authority between the people of the state and the federal government and protect the citizens of the state from the enforcement of a federal law which the people of the state deemed unconstitutional.

The system of segregation of the races imposed after the Civil War in southern and some border states. The origin of the term Jim Crow is not known but may have its origins in a minstrel song.

A paramilitary terrorist organisation founded in Pulaski, Tennessee, after the Civil War. Despite the protestations of some southerners, the Invisible Empire of the Ku Klux Klan was the paramilitary wing of the Democratic party and was instrumental in the overthrow of the Reconstruction governments in the South. The modern KKK was launched in Georgia and claimed five million members by 1925. It not only emphasised issues of race but also gained popularity throughout the United States with its anti-Semitism and anti-Catholicism. It still exists and it is not confined to the South. 
New Deal

Nullification

Ole Miss

Peculiar institution

Sharecropper

Solid South

Territories
The title given by President Franklin Delano Roosevelt to the wide-ranging social and economic legislation which he introduced after his election in 1932, which was designed to regulate the capitalist economy and introduce a welfare state.

The southern argument that every state was sovereign and had the right to declare null and void federal legislation that the people of the state deemed unconstitutional.

The popular title of the University of Mississippi.

This was a euphemism that was used by southerners before the Civil War to describe the institution of slavery. In the North it was used to indicate that slavery was an institution peculiar (i.e. belonged exclusively) to the South.

A tenant farmer in the South who paid for rent and supplies by giving a share of the crop to the landowner.

Following its defeat in the Civil War, the South was governed by Republican state governments which were defeated with the end of Reconstruction. Following 1876, the South voted for one-party rule - by the Democratic party.

Land acquired by the United States was held by the federal government and organised into territories governed by four judges until the population reached 5000 eligible voters. After that they could elect a territorial legislature and send a nonvoting delegate to Congress. When the population reached 60000 , the land was subdivided into congressional districts and a republican constitution was adopted; when Congress had approved these measures, the state was allowed to enter the Union with its own members of the House of Representatives, the number of whom was based on its population, and with two senators. 


\section{ACRONYMS}

ACHR

ACLU

ACMHR

ADA

AFL-CIO

AIM

AME

BIA

CEEO

CIA

COFO

CORE

ERA

FBI

FDR

FEPC

FOR

FSC

HEW

HUAC

IRS

KKK

MFDP

MIA

NAACP
Alabama Council on Human Relations

American Civil Liberties Union

Alabama Christian Movement for Human Rights

Americans for Democratic Action

American Federation of Labor-Congress of Industrial Organizations

American Indian Movement

African Methodist Episcopal

Bureau of Indian Affairs

Commission on Equal Employment Opportunity

Central Intelligence Agency

Council of Federated Organizations

Congress of Racial Equality

Equal Rights Amendment

Federal Bureau of Investigation

Franklin Delano Roosevelt

Fair Employment Practices Commission

Fellowship of Reconciliation

Friends Service Committee

(Department of) Health, Education and Welfare

House Un-American Activities Committee

Internal Revenue Service

Ku Klux Klan

Mississippi Freedom Democratic Party

Montgomery Improvement Association

National Association for the Advancement of

Colored People 
NCAI

NOW

LBJ

ROAR

SCEF

SCLC

SDS

SNCC

UCMI

UT

WPC
National Congress of American Indians

National Organization for Women

Lyndon Baines Johnson

Restore Our Alienated Rights

Southern Conference Education Fund

Southern Christian Leadership Conference

Students for a Democratic Society

Student Nonviolent (in 1965 changed to National)

Coordinating Committee

United Christian Movement Incorporated

The University of Tennessee, Knoxville

Women's Political Council 


\section{Basic Chronology}

1945 Harry S. Truman becomes President on the death of FDR

1947 Truman is the first President to address the annual conference of the NAACP

1948 Both parties support civil rights, but the Democrats split over the issue and Strom Thurmond, governor of South Carolina, leads the resistance, forming the Dixiecrat party

Truman uses executive orders to set up Fair Employment Board and to begin the integration of the armed forces

1954 Brown v Board of Education, Topeka Kansas First White Citizens' Council, Mississippi

1955 Brown II

Segregation on interstate transport banned Montgomery bus boycott begins

1956 Martin Luther King Jr's home is bombed Southern Manifesto published Eisenhower re-elected President Supreme Court orders bus desegregation Bus boycott ends

1957 SCLC established

Little Rock Central High School integration stopped by riots

First Civil Rights Act since 1875

Ghana wins its independence

1959 Massive resistance to school integration starts in Virginia

1960 Sit-in movement starts in Greensboro, North Carolina SNCC set up 
Civil Rights Act becomes law Eleven colonies in Africa gain independence John F. Kennedy elected President

1961 CORE organises 'Freedom Rides'

Kennedy appoints his brother Robert Attorney General and voter registration drive is started

Albany protest starts

1962 Kennedy signs executive order on integration of federal housing

Riots as students resist integration of the University of Mississippi

1963 Albany protest ends

Birmingham, Alabama, demonstrations

George Wallace tries to stop integration of University of Alabama

March on Washington

John F. Kennedy and Medgar Evers killed

1964 LBJ elected President

Martin Luther King Jr wins Nobel Peace Prize

Givil Rights Bill passed

Mississippi Freedom Democratic party established

Rioting in New York, Chicago and Philadelphia

1965 Selma demonstrations

Voting Rights Act becomes law

Malcolm X is murdered

Rioting in Watts, Los Angeles

King's first anti-Vietnam War speech

SNCC advocates black power

1966 Civil rights campaign meets fierce resistance in Chicago

1967 Givil rights demonstrations extended to Cleveland

King attacks Vietnam War

National Organization of Women set up

1968 Poor People's Campaign plans march on Washington

Martin Luther King Jr assassinated in Memphis

Civil Rights Bill enacted

Robert Kennedy assassinated in California

AIM established

LBJ does not seek re-election

Richard Nixon is elected President

1969 Nixon greatly extends the use of affirmative action 
Stonewall gay bar raided in New York City, Gay Liberation Front set up

1970 Nominations of Haynesworth and Carswell defeated

1971 Supreme Court orders desegregation by bussing

1972 Richard Nixon re-elected

Watergate scandal begins to emerge

Equal Rights Amendment campaign begins

1973 Supreme Court legalises abortions in Roe $v$ Wade Second Battle of Wounded Knee

1974 Richard Nixon is the first President to be forced to resign

1976 Jimmy Carter of Georgia elected President; he appoints two black women to his cabinet and extends affirmative action

1980 Ronald Reagan elected President

Reagan's opposition to Voting Rights Act defeated

1981 First cases of AIDS reported

1988 Reagan's veto of the Civil Rights Restoration Act fails George Bush elected President

1990 George Bush first President to veto civil rights law successfully

Civil rights law extended to include the disabled

1991 Bush nominates black conservative, Clarence Thomas, to Supreme Court

1992 William Clinton elected President

1993 Clinton extends Voting Rights Act with Motor Voter Bill Clinton fails to keep his promise to gays in the military 